\title{
Yield performance and GGE biplot analysis of wheat genotypes under two irrigation treatments at El Bajío, Mexico
}

\author{
Juan F. Buenrostro-Rodríguez¹, Ernesto Solís-Moya², Alfredo J. Gámez-Vázquez², Juan C. Raya-Pérez', \\ Andrés Mandujano-Bueno ${ }^{2}$, Francisco Cervantes-Ortiz ${ }^{1}$, Jorge Covarrubias-Prieto ${ }^{1 *}$
}

${ }^{1}$ Tecnológico Nacional de México/I.T. Roque, Carretera Celaya-Juventino Rosas, km 8, CP 38110, Celaya, Guanajuato, México. "Corresponding author (jor_covarru-jrg@hotmail.com).

${ }^{2}$ Instituto Nacional de Investigaciones Forestales, Agrícolas y Pecuarias (INIFAP), Campo Experimental Bajío, Carretera Celaya-San Miguel de Allende, 6.5 km, CP 38110, Celaya, Guanajuato, México.

Received: 23 October 2018; Accepted: 7 February 2019; doi:10.4067/S0718-58392019000200234

\begin{abstract}
In Guanajuato, Mexico, water deficits have dramatically increased in recent years due to over-exploitation of this resource. The objective was to identify high yielding wheat (Triticum spp.) varieties under two irrigation regimes. The experiments were planted at Celaya, Guanajuato, for two consecutive (2013-2014 and 2015-2016) growing seasons (GS). Eleven commercial varieties and nine experimental lines were evaluated under 3 or 4 irrigation regimes; split-plot design with 4 replicates was considered; data on yield performance and its components were measured. There were significant differences between GS and number of irrigation regimes $(\mathrm{p} \leq 0.01)$ for most evaluated traits. ANOVA showed significant differences for all traits in the study, except for the 1000-grains weight. Growing seasons affected yield, grains number $\mathrm{m}^{-2}$ and biomass, mainly; on last cropping season, grain yield was higher $\left(1.8 \mathrm{t} \mathrm{ha}^{-1}\right)$ than first one; strong gluten genotypes were more stable, as compared with the soft gluten genotypes. Some experimental varieties exceeded commercial varieties, which means success in wheat breeding. Genotypes Experimental Line D and control 'Bárcenas F2002' under 3 irrigations regime treatment showed the highest grain yield (7.7 and $7.0 \mathrm{t} \mathrm{ha}^{-1}$, respectively). On 4 irrigations regime, the best yielding genotypes were experimental lines $\mathrm{D}$, and $\mathrm{H}$, with 6.5 and $6.1 \mathrm{t} \mathrm{ha}^{-1}$, respectively. Based on regression deviations the most stable and predictable wheat genotypes were strong gluten genotypes.
\end{abstract}

Key words: Grain yield, growing seasons, irrigation regimes, stability, Triticum spp., wheat genotypes.

\section{INTRODUCTION}

Wheat crop (Triticum spp.) in Guanajuato State, Mexico, is planted at the fall-winter (FW) cropping season (NovemberMay) under irrigation. Main problems affecting wheat production is water shortage (Solís et al., 2014). The low water availability of surface bodies and the growing pollution exacerbate the resource depletion.

Direct selection for yield is generally the simplest, most effective way to improve yield and hence, water use efficiency (WUE) in crops. Plant breeding plays an important role to release new varieties with higher grain yield under low water requirements; hence, it is necessary to apply selection methods to identify more efficient water use genotypes. The improvements in yield have arisen mainly from an increase in harvest index (HI) rather than biomass (Tardieu, 2013).

Moreno-Ramos et al. (2010) indicates that it is possible to produce adequate grain yields with only 3 irrigations regime: one at planting date and two more along the cropping season, instead of the 4 irrigations regime that are currently applied in Northwest and Bajío regions of Mexico. Ledesma et al. (2010) evaluated two irrigation calendars (3 and 4) under 3 tillage systems; they pointed out that irrigation regimes number significantly affected grain yield in the 3 tillage 
systems, where four-irrigation regime produced higher yields. There were higher yields with 4 irrigations regime and 160 and $240 \mathrm{~kg} \mathrm{~N}^{-1}$ traits.

Solís et al. (2009) pointed out that 4 irrigations regime produced $2000 \mathrm{~kg} \mathrm{ha}^{-1}$ higher when planting on 1 December than planting on 15 January. When planting date was on $1^{\text {st }}$ December, with 3 irrigations regime, wheat production was $450 \mathrm{~kg} \mathrm{ha}^{-1}$ higher than 4 irrigations regime and planting date on 15 January, because in late planting dates, grain-filling period is exposed to high temperatures that accelerate leaf senescence.

López-Bellido et al. (2007) summarized their results of water deficit effect on wheat performance in 3 phenological stages. 1) Crop is sensitive to water deficit on reproductive organs stage and at flowering time. 2) Water deficit at growth stage significantly reduces grain yield due to reduction in spike grains number. 3 ) Reproductive organ tissues are susceptible to damage from water deficit, thus affecting pollen formation as well as fertilization. Wheat yields are the result of 3 components: panicles number per area unit, panicle grain number and grain size. Yield components are largely developed in sequence and the time when water stress occurs determines which of the components will be affected (Steduto et al., 2012; Tardieu, 2013). Therefore, early stress limits tillers number, and stress after anthesis reduces individual grains size and grain number through abortion of developing grains; flowering stage is the most sensitive to water shortage; management practices are equally important as breeding under water-limited conditions (Passioura and Angus, 2010). In most cases, however, performance correlates positively with grains number $\mathrm{m}^{-2}$. Therefore, grains number $\mathrm{m}^{-2}$, and hence tillers number, is generally the most important determinant of wheat performance. Respect to this, applying irrigation at flowering time and at grain formation stages, Li et al. (2010) obtained the highest wheat grain yield.

The Wheat Breeding Program at Instituto Nacional de Investigaciones Forestales, Agrícolas y Pecuarias (INIFAP) in Guanajuato state, Mexico, has generated new high yielding genotypes, which are water use efficient, as well as other traits, such as increased resistance to rust as compared to early commercial varieties of strong gluten. Solís et al. (2008) indicated that under 2 or 3 irrigation regimes treatments, Urbina S2007 wheat variety exceeded in performance to all evaluated varieties: 'Salamanca S75' by $17.1 \%$ and 'Bárcenas S2002' by 4\%. 'Luminaria F2012' under restricted irrigation, exceeded 'Salamanca S75' by 9\% (Solís et al., 2014). With respect to WUE, under 4, 3 and 2 irrigations regimes treatments, 'Barcenas S2002' exceeded in performance to 'Salamanca S75' by $12.1 \%$, 6.0\% and 4.5\%, respectively (Solís et al., 2016).

Research objective was to evaluate performance of 20 wheat genotypes (11 commercial varieties and 9 experimental lines) for yield and yield components over two cropping seasons under 3 and 4 irrigations regimes, and to select more efficient water use genotypes. Hypothesis was that plant breeding has been effective in developing high yielding genotypes under water shortage.

\section{MATERIALS AND METHODS}

This research was conducted at the Bajío Experimental Station (CEBAJ) of Instituto Nacional de Investigaciones Forestales, Agrícolas y Pecuarias (INIFAP), located in Celaya (20³5'17.43” N, 10049’74.96” W; 1725 m a.s.1.), Guanajuato, Mexico. Two field experiments were conducted in both fall-winter (FW) 2013-2014 and FW 2015-2016 growing seasons to evaluate the effects of two irrigation regimes on 20 spring wheat genotypes for yield performance; trials were established at second half of December of each growing season. Sowing rate was $120 \mathrm{~kg} \mathrm{ha}^{-1}$; fertilization dose was 240-60-00 split in two applications, half of $\mathrm{N}$ and all the $\mathrm{P}$ at planting date, and the rest of $\mathrm{N}$, before the first irrigation. The 20 genotypes comprised 11 commercial varieties and nine experimental lines (Table 1) from INIFAP wheat breeding program, under two irrigation treatments: 4 irrigations regime (42 cm total water supply) were applied at 0-45-75-100 d after sowing (das) and 3 irrigations regime ( $32 \mathrm{~cm}$ total water supply): 0-45-75 das, respectively. Water distribution was as follows: $12,10,10$, and $12,10,10$ and $10 \mathrm{~cm}$ for 3 and 4 irrigations regime, respectively. The experiments were conducted in a split-plot design with four replicates; irrigation regimes were assigned to the main plot and the genotypes to the subplot. Each experimental plot consisted of two lines between rows; rows were $75 \mathrm{~cm}$ apart and $3 \mathrm{~m}$ length. Harvest was performed with a mini combined thresher machine for experimental plots; a 2 m-length plot was threshed in each experimental unit; grain yield in grams per plot was measured and converted to $\mathrm{kg} \mathrm{ha}^{-1}$. The plants from the remaining 
Table 1. Wheat genotypes evaluated in the fall-winter growing seasons 2013-2014 and 2015-2016 at the Bajío Experimental Research Station.

\begin{tabular}{rll}
\hline $\mathrm{Nr}$ & ID & \multicolumn{1}{c}{ Genealogy } \\
\hline 1 & $\mathrm{~A}$ & Wbll1*2/Brambling \\
2 & $\mathrm{~B}$ & Corocoro/3/Pasa/Ciria//Ene \\
3 & $\mathrm{C}$ & ///kauz Altar84/Aos/3/Milan/kauz/4/Huites/7/Cal/Nh//H567,71/3/Seria \\
4 & $\mathrm{D}$ & Tacupeto F2001/Brambling*2/5/Kauz//Altar84/Aos/3/Milan/Kauz/4 \\
5 & $\mathrm{E}$ & Cndoa/Ee/Celtic/3/Pata_2/6/Aram_7//Crex/Alla/5Ente/Mexi_2//Hui \\
6 & $\mathrm{~F}$ & $/ /$ kauz Altar84/Aos/3/Milan/kauz/4/Huites/5/C80.1/3*B \\
7 & $\mathrm{G}$ & //kauz Altar84/Aos/3/Milan/kauz/4/Huites/5/prinia/Pas//Huites \\
8 & $\mathrm{H}$ & Ibis//Loth/Gracia \\
9 & $\mathrm{I}$ & kauz//Altar84/Aos/3/Milan/kauz/4/Huites/5;Croc_1/A \\
10 & & Cortazar S94 \\
11 & & Urbina S2007 \\
12 & & LuminariaF2012 \\
13 & & Maya S2007 \\
14 & & Bárcenas S2002 \\
15 & & Norteña F2007 \\
16 & & Eneida F94 \\
17 & & Nana F2007 \\
18 & & Alondra F2014 \\
19 & & Saturno S86 \\
20 & & Salamanca S75 \\
\hline
\end{tabular}

ID: Identifier of experimental lines.

plot were cut out at ground level, and 100 stalks were randomly selected. These stalks were weighed, and then shelled for estimating harvest index. The following formulas were used to estimate yield components:

$$
\begin{aligned}
& \text { Harvest index }=\text { Grain weight from } 100 \text { stems }(\mathrm{g}) / \text { Weight from } 100 \text { stems }(\mathrm{g}) \\
& \text { Biomass }=\left(\text { Yield of plot }\left(\mathrm{kg} \mathrm{ha}^{-1}\right) / 1000\right) / \text { Harvest index } \\
& \text { Grains per square meter }=\left(\text { Yield }\left(\mathrm{kg} \mathrm{ha}^{-1}\right) / 10\right) /(\text { Weight } 1000 \text { grains }(\mathrm{g}) / 1000) \\
& \text { Wheat spikes per square meter }=\left(\text { Biomass }\left(\mathrm{t} \mathrm{ha}^{-1}\right) 100\right) /(\text { Weight } 100 \text { stems }(\mathrm{g}) / 100)
\end{aligned}
$$

Statistical data analysis was conducted through an ANOVA, pooled over growing seasons, and means comparison was performed by Tukey test $(\mathrm{p} \leq 0.05)$; an analysis of principal components was performed using SAS 9.3 routines (SAS Institute, Cary, North Carolina, USA). The GEI analysis was implemented according to McDermott and Coe (2012), where the origin of the biplot corresponds to the standardized general mean, and the axes of the abscissa and the ordinate to the yield of genotypes in four and three irrigations regime, respectively. The GGE-biplot shows the first 2 principal components (PC1 and PC2).

\section{RESULTS}

Pooled ANOVA over growing seasons (Table 2) revealed significant differences between growing seasons $(\mathrm{p} \leq 0.01)$ for all traits, except for thousand-grain weight; most of variation in this trait was determined by genotypes but irrigation was not as important. There were highly significant differences between irrigation regimes $(\mathrm{p}<0.01)$ for all traits, except for spikes number $\mathrm{m}^{-2}$, which appears to be more affected by genotype and environmental conditions between growing seasons (two in this case). Highly significant differences were observed $(\mathrm{p}<0.01)$ among genotypes for all studied traits, indicating a wide genetic variability among the evaluated genotypes (varieties and experimental lines); there were significant differences $(\mathrm{p} \leq 0.05)$ for spikes number $\mathrm{m}^{-2}$ trait. Irrigation $\times$ Growing season and Genotype $\times$ Growing season interactions were significant, indicating that some genotypes had different performance between growing seasons; irrigation effect was different between growing seasons, mainly due to differences in temperatures, which were lower in last growing season. The most important interactions for its effect on variability was Irrigation $\times$ Growing season and Genotype $\times$ Growing season for all evaluated traits, except for thousand-grain weight, which appeared to be more affected by genotypes and irrigation. Coefficients of variation were good (Gomez and Gomez, 1984), ranging from 3.8\% to 15.8\%. The greatest influence of environment was for yield, spikes number $\mathrm{m}^{-2}$ and grains number $\mathrm{m}^{-2}$ plus biomass traits; growing 
Table 2. Estimated mean squares of traits measured in $\mathbf{2 0}$ wheat genotypes evaluated with two irrigations regimes during two fall-winter growing seasons, 2013-2014 and 2015-2016 at the Bajío Experimental Research Station.

\begin{tabular}{|c|c|c|c|c|c|c|c|}
\hline \multirow[b]{2}{*}{$\begin{array}{l}\text { Sources of } \\
\text { variation }\end{array}$} & \multirow[b]{2}{*}{ DF } & \multicolumn{6}{|c|}{ Mean squares } \\
\hline & & Yield & $\begin{array}{c}\text { Grains } \\
\text { number } \mathrm{m}^{-2}\end{array}$ & $\begin{array}{c}\text { Spikes } \\
\text { number } \mathrm{m}^{-2}\end{array}$ & $\begin{array}{l}\text { Grain number } \\
\text { spikes }^{-1}\end{array}$ & $\begin{array}{c}\text { Thousand -grains } \\
\text { weight }\end{array}$ & Biomass \\
\hline GS & 1 & $275.541 * *$ & $731150641 * *$ & $1672212 * *$ & $766.941 * *$ & $0.635 \mathrm{~ns}$ & $2219.724 * *$ \\
\hline GS (repl) & 6 & 1.498 & 4085814 & 6829 & 7.583 & 7.894 & 13.710 \\
\hline $\mathrm{R}$ & 1 & $52.553 * *$ & $174106939 * *$ & $5118 \mathrm{~ns}$ & $2215.512 * *$ & $51.000^{*}$ & $281.400 * *$ \\
\hline $\mathrm{R} * \mathrm{GS}$ & 1 & $29.756 * *$ & $69834066 * *$ & $23963 *$ & $469.480 * *$ & 4.336ns & $43.645^{*}$ \\
\hline Error (a) & 6 & 0.327 & 434070 & 1889 & 16.225 & 8.456 & 3.266 \\
\hline G & 19 & $3.589 * *$ & $8810506^{* *}$ & $18719 *$ & $156.192 * *$ & $148.533^{* *}$ & $21.376^{* * *}$ \\
\hline $\mathrm{G} \times \mathrm{GS}$ & 19 & $0.937 * *$ & $2344534 * *$ & $8143 *$ & $31.710^{* * *}$ & $1.124 \mathrm{~ns}$ & $6.302 *$ \\
\hline $\mathrm{G} \times \mathrm{R}$ & 19 & $0.839 * *$ & $2458173 \mathrm{~ns}$ & $2821 \mathrm{~ns}$ & $10.869 \mathrm{~ns}$ & $23.016^{*}$ & $5.825^{*}$ \\
\hline $\mathrm{G} \times \mathrm{R} \times \mathrm{GS}$ & 19 & $0.579 * *$ & $1368601 \mathrm{~ns}$ & $3512 \mathrm{~ns}$ & $30.137 \mathrm{~ns}$ & $0.661 \mathrm{~ns}$ & $4.617 \mathrm{~ns}$ \\
\hline Error (b) & 228 & 0.289 & 988323 & 3049 & 15.350 & 5.460 & 3.413 \\
\hline $\mathrm{CV}(\mathrm{a}), \%$ & & 9.2 & 6.5 & 12.4 & 13.5 & 4.7 & 12.9 \\
\hline $\mathrm{CV}(\mathrm{b}), \%$ & & 8.7 & 9.8 & 15.8 & 13.1 & 3.8 & 13.2 \\
\hline
\end{tabular}

*,** Significant at the 0.05 and 0.01 probability levels, respectively.

ns: Nonsignificant; repl: replication, DF: degrees of freedom, GS: growing season, R: irrigations regimes, G: genotypes, CV: coefficient of variation.

seasons contributed $50.31 \%$, irrigation with $9.6 \%$, Irrigation $\times$ Growing season interaction with $5.43 \%$ and genotypes with $12.45 \%$ of the observed total variance for yield. Last three interactions contributed $8.17 \%$ of total variance.

On FW 2015-2016 growing season, more favorable environmental conditions for wheat production were observed; in general, increased production was obtained: $1.8 \mathrm{tha}^{-1}$ grain yield, $5.2 \mathrm{t} \mathrm{ha}^{-1}$ biomass, 144 spikes number $\mathrm{m}^{-2}$ and 3023 grains number $\mathrm{m}^{-2}$, as compared to FW 2013-2014 growing season (Table 2). The 4 irrigations regime allowed to obtain $810 \mathrm{~kg} \mathrm{ha}^{-1}$ more than 3 irrigations regime because of increased soil water availability for varieties development, supported with a higher biomass production $\left(1.8 \mathrm{t} \mathrm{ha}^{-1}\right)$, higher grains number spike-1 (5.2) and higher grains number $\mathrm{m}^{-2}(1475)$.

FW 2015-2016 growing season exceeded in performance to FW 2013-2014 for grain yield (35.36\%), grains number $\mathrm{m}^{-2}$ (35.3\%), spikes number $\mathrm{m}^{-2}(52.36 \%)$ and biomass (46.45\%); spike grains number and thousand-grain weight traits had different (reduction) performance (Table 3). However, grains number spike ${ }^{-1}$ was higher in FW 2013-2014 growing season $(10.93 \%)$, but nonsignificant differences in thousand-grain weight were observed; Table 3 also shows that 4 irrigations regime application contributed to increase yield (14.04\%), grains number $\mathrm{m}^{-2}(15.79 \%)$, grains number spike-1 $(19.31 \%)$ and biomass (14.4\%), as compared to 3 irrigations regime.

\section{Genotype $\times$ Environment (GE) interaction analysis}

The most important traits for principal component 1 (PC1) were yield, grains number $\mathrm{m}^{-2}$ and biomass (Table 4); for principal component 2 (PC2) were grains number spike ${ }^{-1}$ and thousand-grain weight; the first two principal components

Table 3. Mean comparisons between cultivation cycles and irrigation schedules of the characters measured in 20 wheat genotypes evaluated with two irrigation schedules during the fall-winter growing seasons 2013-2014 and 2015-2016 at the Bajío Experimental Research Station.

\begin{tabular}{|c|c|c|c|c|c|c|}
\hline \multirow[b]{2}{*}{$\begin{array}{l}\text { Sources of } \\
\text { variation }\end{array}$} & \multicolumn{6}{|c|}{ Mean squares } \\
\hline & Yield & $\begin{array}{c}\text { Grains } \\
\text { number } \mathrm{m}^{-2}\end{array}$ & $\begin{array}{c}\text { Spikes } \\
\text { number } \mathrm{m}^{-2}\end{array}$ & $\begin{array}{l}\text { Grain number } \\
\text { spikes }^{-1}\end{array}$ & $\begin{array}{c}\text { Thousand -grains } \\
\text { weight }\end{array}$ & Biomass \\
\hline & $\mathrm{t} \mathrm{ha}^{-1}$ & & & & $\mathrm{~g}$ & $\mathrm{tha}^{-1}$ \\
\hline \multicolumn{7}{|c|}{ Growing season } \\
\hline 2015-2016 & $7.105 \mathrm{a}$ & $11588.6 \mathrm{a}$ & $420.703 a$ & $28.330 \mathrm{~b}$ & $61.5156 \mathrm{~ns}$ & $16.6087 \mathrm{a}$ \\
\hline 2013-2014 & $5.249 b$ & $8565.4 b$ & $276.126 b$ & $31.426 \mathrm{a}$ & $61.4266 \mathrm{~ns}$ & $11.3412 b$ \\
\hline \multicolumn{7}{|c|}{ Irrigations regimes } \\
\hline Four & $6.5827 \mathrm{a}$ & $10814.6 \mathrm{a}$ & $344.415 \mathrm{~ns}$ & $32.5094 a$ & $61.0719 \mathrm{~b}$ & $14.9127 \mathrm{a}$ \\
\hline Three & $5.7722 b$ & $9339.4 b$ & $352.414 \mathrm{~ns}$ & $27.2469 b$ & $61.8703 \mathrm{a}$ & $13.0372 \mathrm{~b}$ \\
\hline
\end{tabular}

Means with different letters for each trait are significantly different according to Tukey's test ( $\mathrm{p} \leq 0.05)$. ns: Nonsignificant. 
Table 4. Characteristic vectors of the main components for agronomic variables measured in 20 wheat genotypes evaluated during fall-winter growing seasons 2013-2014 and 2015-2016 at the Bajío Experimental Research Station.

\begin{tabular}{lcc}
\hline & \multicolumn{2}{c}{ Characteristic vectors } \\
\cline { 2 - 3 } Variables & $\mathrm{CP} 1$ & $\mathrm{CP} 2$ \\
\hline Yield & 0.504141 & 0.108560 \\
Grains number m $^{-2}$ & 0.508047 & 0.226485 \\
Spikes number $^{-2}$ & 0.466382 & -0.324588 \\
Grains number spike $^{-1}$ & -0.051715 & 0.799642 \\
Thousand-grains weight & -0.013357 & -0.437082 \\
Biomass & 0.517074 & 0.033076 \\
\hline Characteristic value & 3.575 & 1.375 \\
Percentage of explained variance & 59.6 & 22.9 \\
\hline
\end{tabular}

obtained by singular value decomposition of the centered data of yield accounted for $82.5 \%$ of total variability caused by G×GE. Genotypes were grouped into two classes (Figure 1), where main difference was between evaluation growing seasons. The partitioning of GxGE through GGE-biplot analysis showed that PC1 and PC2 were significant factors, explaining $59.6 \%$ and $22.9 \%$ of GGESS (sum of squares), respectively. Yield data were also analyzed using the GGE biplot method. Growing season (GS) and irrigation regimes (R) explained $74 \%$ and $14 \%$, respectively, of the total $(\mathrm{G}+\mathrm{GS}+\mathrm{GGS})$ variation, whereas G and GGSI accounted for $18.3 \%$ and $9 \%$, respectively.

Figure 1. Bi-plot analysis of 20 wheat genotypes evaluated in two irrigations regimes during fall-winter growing seasons 2013-2014 and 2015-2016 at the Bajío Experimental Research Station, Guanajuato, Mexico.

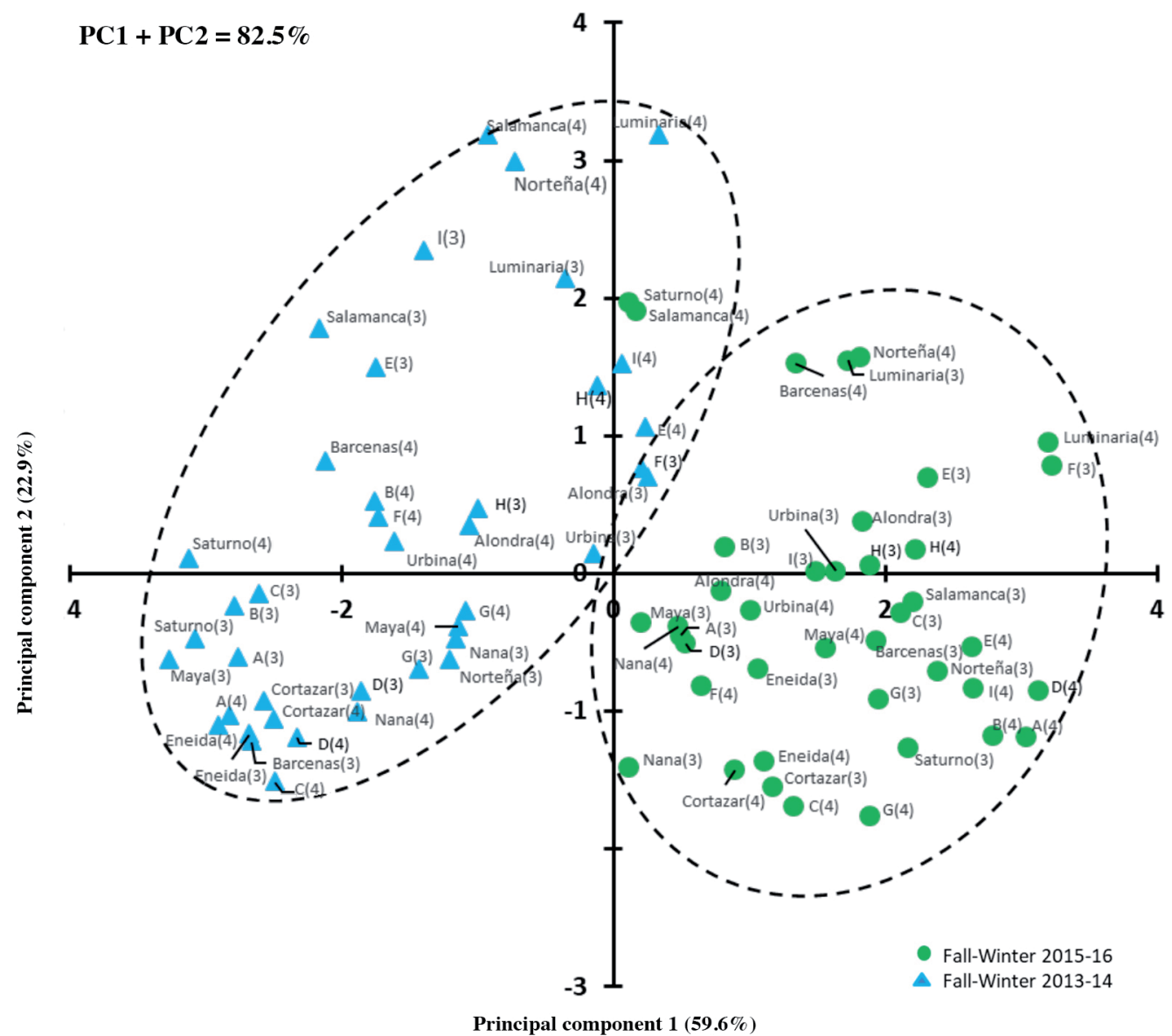


On FW 2015-2016 growing season (Figure 1), higher yields were observed based on a higher biomass production and higher grains number $\mathrm{m}^{-2}$, where the most exceeded in performance genotypes were: $\mathrm{F}$ (with only 3 irrigations regime), and 'Luminaria F2012', D, A, B, I and E (all with 4 irrigations regime). Both growing seasons, FW 2015-2016 and FW 2013-2014, the exceeded in performance genotypes were agronomically similar to control 'Luminaria F2012', exceeded only by genotype F. 'Alondra F2014' and F genotypes (3 irrigations regime) and E and I genotypes (4 irrigations regime) were the best high yielding, but unstable. On FW 2015-2016 growing season, H, Urbina and I (3 irrigations regime) were the most stable and good yielding potential genotypes.

On FW 2013-2014 growing season, again, control 'Luminaria F2012' (4 irrigations regime) was the only one with best agronomic performance, but unstable; besides genotypes F (3 irrigations regime), 'Alondra F2014' (3 irrigations regime), and E (4 irrigations regime) were also high yielding but with better stability than 'Luminaria F2012'; this varieties performed similar to control 'Saturno S86' and 'Salamanca S75' (FW 2015-2016 cropping season, both evaluated under 4 irrigations regime). On this growing season, genotypes I, 'Alondra F2014' and F were similar for agronomic characteristics as 'Luminaria F2012', but genotypes 'Alondra F2014' and F required only 3 irrigations regime, as compared to 'Luminaria F2012'. Most varieties in this growing season were high yielding but unstable.

A high variation was observed overall in the results among evaluated genotypes; genotypes with less favorable agronomic performance for both FW 2013-2014 and FW 2015-2016 growing seasons were control 'Saturno S86', 'Cortazar S94', 'Eneida F94' and 'Nana F2007' under 3 and 4 irrigations regimes; also, these varieties showed low biomass accumulation, fewer grains number $\mathrm{m}^{-2}$ and less yield.

Figure 2 shows the standardized yield of the 20 genotypes evaluated under 3 (y-axis) and 4 (abscissa axis) irrigations regime. Genotype D and control 'Bárcenas F2002', obtained the highest grain yields (7.7 and $7.0 \mathrm{t} \mathrm{ha}^{-1}$, respectively) under 3 irrigations regime; on 4 irrigations regime, the best yielding genotypes were $\mathrm{D}$, and $\mathrm{H}$, with 6.5 and $6.1 \mathrm{t} \mathrm{ha}^{-1}$, respectively. The only high yielding genotypes in all evaluation environments ( 3 and 4 irrigations regimes and two growing seasons), were $\mathrm{D}$ and $\mathrm{H}$; the effect of decreasing one irrigation regime in both genotypes was 1.2 and $1.52 \mathrm{t} \mathrm{ha}^{-1}$, respectively.

Straight line regression was fitted (Figure 2) with four evaluation environments; genotypes were classified by their stability performance. Therefore, based on deviations of regression, the most stable and predictable genotypes were: 'Saturno S86', C, 'Alondra F2014', 'Luminaria F2012', I, 'Nana F2007' and 'Nortena F2007'; all these genotypes are strong gluten except Saturn o S86. The less stable genotypes were 'Bárcenas F2007', B, 'Cortazar S94' and Maya, which are soft gluten. 'Luminaria F2012' (control) and 'Alondra F2014' were high yielding and of greater stability varieties, but were not superior to genotypes $\mathrm{D}$ and $\mathrm{H}$.

Figure 2. Standardized performance and stability of 20 wheat genotypes evaluated on 3 and 4 irrigations regimes during the fall-winter growing seasons 2013-2014 and 2015-2016 at the Bajío Experimental Research Station, Guanajuato, Mexico.

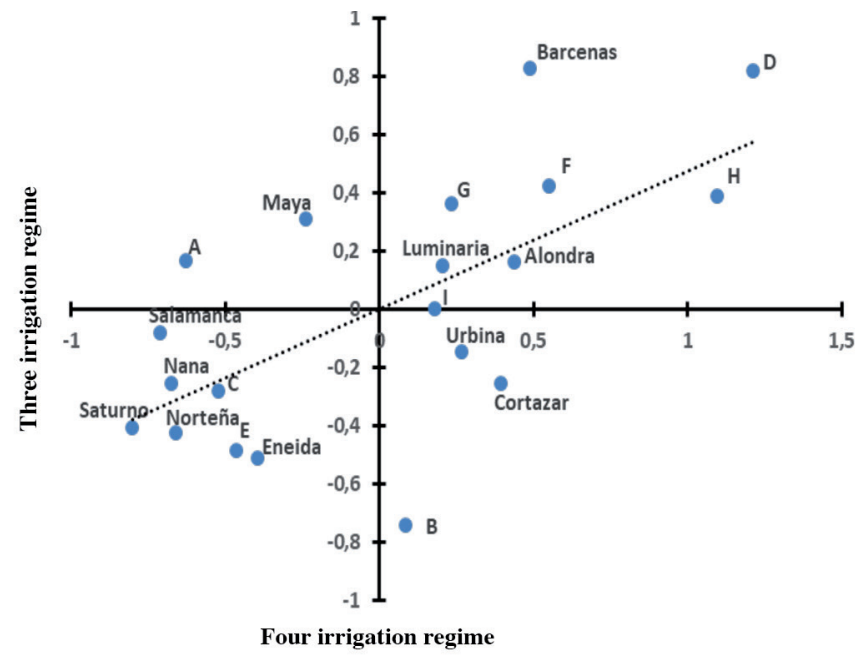


Finally, higher performance genotypes, stable and therefore, agronomically desirable were: D that yielded 7.8 and $6.6 \mathrm{tha}^{-1}$ under 4 and 3 irrigations regimes, respectively, and $\mathrm{H}$ that yielded 7.7 and $6.2 \mathrm{tha}^{-1}$ under 4 and 3 irrigations regimes treatments, respectively.

\section{DISCUSSION}

Genotypes explained most variation between growing seasons (pooled ANOVA over growing seasons) for most traits (Table 2) and to a lesser extent by irrigation; this shows random variability among growing seasons, as usual. Highly significant differences between irrigation regimes $(\mathrm{p}<0.01)$ were observed for all traits, but not spikes number $\mathrm{m}^{-2}$, which appears to be more affected by genotype and environmental conditions between growing seasons (two in this case); higher water availability allowed some varieties to better develop their genetic potential; this was consistent with results of Ledesma et al. (2010), Li et al. (2010), Passioura and Angus (2010). Highly significant differences were observed among genotypes for evaluated traits, due to genetic differences among the evaluated genotypes (varieties and experimental lines) and effectiveness of traditional wheat breeding; differences were significant for spikes number $\mathrm{m}^{-2}$ trait. Irrigation $\times$ Growing season and Genotype $\times$ Growing season interactions were significant, which indicates that some genotypes had different performance between irrigation regimes and growing seasons, and hence, their ability to perform better in some environmental conditions; these results are consistent with Moreno-Ramos et al. (2010); the irrigation effect was different between growing seasons, mainly due to differences in temperatures, which were lower in the last growing season; this led to an increase in the biological cycle and therefore, higher wheat yield (Asseng et al., 2011; Tardieu, 2013).

Among interactions, the most important for its effect on the variability was Irrigation $\times$ Growing season for most of the evaluated traits, but not for thousand-grain weight. Genotype $\times$ Growing season interaction had higher effect on the response to the evaluated traits, since significant differences for all traits were observed, except for thousand-grain weight, which appeared to be more affected by genotypes and irrigation regimes. Yield differences among varieties were due to the combined effects of traits, grains number and spikes number $\mathrm{m}^{-2}$, grains number spike $\mathrm{e}^{-1}$ and thousandgrain weight, since they are important components for the expression in respect thereof; the highest variation was determined by growing seasons environmental conditions of assessment; thousand-grain weight was the only trait that was defined mainly by genotypes genetic variability, as they accounted for over $61 \%$ of the total variation. Genotypes had differences in their performance through growing seasons, because some varieties and experimental lines have adaptation to specific environmental conditions. Genotypes contributed about $12.45 \%$ of the total variation for the expression of the traits: biomass production, yield, grains number spike ${ }^{-1}$ and spikes number $\mathrm{m}^{-2}$, grains number spike ${ }^{-1}$ explained $4.2 \%$ of the total variance.

The highest environment influence was for traits, yield, spikes number $\mathrm{m}^{-2}$ and grains number $\mathrm{m}^{-2}$ plus biomass, where growing seasons contributed $50.31 \%$, irrigation with $9.6 \%$, Irrigation $\times$ Growing season interaction with $5.43 \%$ of the total observed variance. Approximately, $25 \%$ of growing seasons variation was explained by genotypes variation.

On the FW 2015-2016 growing season, more favorable environmental conditions for wheat production were observed; in general, increased production was obtained: $1.8 \mathrm{t} \mathrm{ha}^{-1}$ grain yield, $5.2 \mathrm{t} \mathrm{ha}^{-1}$ biomass, 144 spikes $\mathrm{m}^{-2}$ and 3023 grains $\mathrm{m}^{-2}$, as compared to FW 2013-2014 growing season (Table 2). The 4 irrigations regime application yielded $810 \mathrm{~kg} \mathrm{ha}^{-1}$ higher than applying 3 irrigations regime because of increased water availability in the soil for development of varieties supported with a higher biomass production $\left(1.8 \mathrm{t} \mathrm{ha}^{-1}\right)$, higher grains number spike-1 (5.2) and higher grain number $\mathrm{m}^{-2}$ (1475); this result was expected due to increased water availability resources to better performing physiological activities (Tardieu, 2013).

The FW 2015-2016 growing season was of higher productivity (35.36\% for grain yield, $35.3 \%$ for grains $\mathrm{m}^{-2}, 52.36 \%$ spikes $\mathrm{m}^{-2}$ and $46.45 \%$ for biomass, as compared to FW 2013-2014 growing season; the exception were traits, grains number spike ${ }^{-1}$ and thousand-grain weight, that were lower (Table 3). However, spike grains number was higher on growing season FW 2013-2014 (10.93\%), but non-significant differences in thousand-grain weight were observed; this indicates, possibly, that although larger number of grains per spike was obtained in this growing season, the environmental conditions were not suitable to take advantage to increased thousand-grain weight. 
Table 3 shows that 4 irrigations regime application contributed to increased yield (14.04\%), grains number $\mathrm{m}^{-2}(15.79 \%)$, spike grains number $(19.31 \%)$ and biomass $(14.4 \%)$, which was expected due to the higher moisture availability for the expression of all these characteristics and low temperatures that promoted higher tilling; this yield increase was mainly due to the effect of higher grains $\mathrm{m}^{-2}$ and spike grains number; spike grains number was higher with 4 irrigations regime (19.31\%), which agrees with Passioura and Angus (2010), who pointed out that by restricting irrigation, this characteristic was diminished; with 4 irrigations regime, thousand grains weight was lower $(1.31 \%)$ than 3 . Restriction in irrigation regimes number reduced yield and other traits evaluated, which agrees with López-Bellido et al. (2007) and Steduto et al. (2012) on the effect of water shortage stress. Results of Li et al. (2010) partially agree with those obtained in this research, since 4 irrigations regime did not affect water availability in the stages of flowering and grain formation. Some genotypes on 3 irrigations regime exceeded in performance to control varieties, which agrees with Moreno-Ramos et al. (2010). The GGEI biplot ranked genotypes by their mean yield capacity and stability in a number of environments.

\section{Genotype $\times$ Environment interaction analysis}

In FW 2015-2016 growing season (Figure 1), higher yields were observed based on a higher biomass production and higher grains number $\mathrm{m}^{-2}$, where the most high yielding genotypes also had a higher spike grains number: $\mathrm{E}$ and $\mathrm{F}$ or higher thousand grains weight: E, I, B, A and D genotypes. In both growing seasons, the best genotypes were agronomically similar to control 'Luminaria F2012'; genotype F was evaluated only with 3 irrigations showing that wheat breeding was effective to select high yielding genotypes with restricted irrigation regime (Moreno-Ramos et al., 2010).

FW 2013-2014 growing season, control 'Luminaria F2012' with 4 irrigations regime was the best in agronomic performance, even equating the control 'Saturno S86' and 'Salamanca S75', both under 4 irrigation regime FW 20152016 growing season; similar reports were obtained by Solís et al. (2014), who pointed out that 'Luminaria F2012' was $9 \%$ higher in performance as compared to 'Salamanca S75' under restricted irrigation. In this growing season, genotypes I, 'Alondra F2014' and F were similar in agronomic performance response as 'Luminaria F2012', with the advantage for genotypes 'Alondra F2014' and F with one irrigation less (Moreno-Ramos et al., 2010). Solís et al. (2016) reported that 'Alondra F2014' was higher yielding than 'Salamanca S75', 'Cortazar S94', 'Maya S2007', 'Luminaria F2012' and 'Bárcenas S2002'.

A large variation was observed overall in the results of evaluated genotypes; new experimental lines showed that wheat breeding has been successful. Genotypes that had PC1 scores higher than zero were high yielding (except genotype C) while genotypes that had PC1 less than zero scores were identified as lower yielding or non-adaptable (except genotype O). The high yielding genotypes can be divided into stable and unstable groups, were high yielding as well as stable, since their absolute PC2 scores was near zero.

Figure 2 shows the standardized yield of 20 genotypes evaluated with 3 (y-axis) and 4 (abscissa axis) irrigations regimes. On 4 irrigations regime, genotype D and 'Bárcenas F2002' (control) showed the highest grain yields (7.7 and $7.0 \mathrm{t} \mathrm{ha}^{-1}$, respectively), followed by $\mathrm{I}$, and $\mathrm{H}$ genotypes, with 6.5 and $6.1 \mathrm{t} \mathrm{ha}^{-1}$, respectively. The best genotype in all evaluation environments ( 3 and 4 irrigations regimes and two growing seasons), was D, which produced less grain, 1.2 and $1.52 \mathrm{t} \mathrm{ha}^{-1}$, respectively, by irrigation reduction.

Villaseñor et al. (2012) mentioned that 'Norteña F2007' was higher yielding than 'Bárcenas F2002' under restricted irrigation, probably because evaluation were done in a larger number of environments (nine Mexican states). F was a high yielding genotype at both 2013-2014 and 2014-2015 growing seasons under 3 irrigations regime, which agrees with Moreno-Ramos et al. (2010), who reported that plant breeding has indirectly increased water use efficiency in wheat because yield has increased without additional water use and that it is possible to produce adequate grain yield under water restriction.

A straight regression line was fitted considering the four evaluation environments; genotypes were classified by their stability performance. Thus, based on deviations of regression, the most stable and predictable genotypes were 'Saturno S86', C, 'Alondra F2014', 'Luminaria F2012', I, 'Nana F2007' and 'Norteña F2007', which are strong gluten; the exception was 'Saturno S86'. The least stable genotypes were 'Bárcenas F2007', B, 'Cortazar S94' and 'Maya S2007', which are soft gluten varieties.

Finally, higher performance genotypes, stable and therefore, agronomically desirable, were: D, which yielded 7.8 and $6.6 \mathrm{tha}^{-1}$ with 4 and 3 irrigations regimes, respectively, and $\mathrm{H}$ genotype, which yielded 7.7 and $6.2 \mathrm{t} \mathrm{ha}{ }^{-1}$ with 4 and 
3 irrigations regimes, respectively. Some genotypes were water-use efficient, which means breeding was effective for selecting best genotypes under water use reduction (Passioura and Angus, 2010; Li et al., 2010).

\section{CONCLUSIONS}

Growing seasons had higher influence on yield and its components; Irrigation $\times$ Growing season interaction had higher effect than genotypes. The thousand-grain weight was mainly affected by genotypes and irrigations regimes number. Genotypes had the highest influence on the expression of spikes number $\mathrm{m}^{-2}$ and thousand-grain weight traits, as compared to irrigation regimes number. Interaction Genotype $\times$ Growing seasons was significant for all traits. Genotype $\times$ Irrigation interaction had low effect on yield. Strong gluten genotypes were more agronomically stable, as compared to soft gluten. Wheat genetic improvement has contributed with significant achievements, by outperforming the commercial genotypes. Water use efficiency was highly correlated with yield.

\section{ACKNOWLEDGEMENTS}

We acknowledge the support of CONACYT for providing the PhD scholarship for Francisco Buenrostro-Rodriguez. This project was financed by INIFAP-CEBAJ Mexico. We also acknowledge Bajío Experimental Research Station.

\section{REFERENCES}

Asseng, S., Foster, I., and Turner, N.C. 2011. The impact of temperature variability on wheat yields. Global Change Biology 17(2):997-1012. doi:10.1111/j.1365-2486.2010.02262.x.

Gomez, K.A., and Gomez, A.A. 1984. Statistical procedures for agricultural research. $2^{\text {nd }}$ ed. 680 p. John Wiley \& Sons, New York, USA.

Ledesma, L., Solis, E., Suaste, M.P., y Rodríguez, M.F. 2010. Relación de métodos de labranza, siembra, riego y dosis de nitrógeno con el rendimiento de trigo. Revista Mexicana de Ciencias Agrícolas 1(1):55-63.

Li, Q.Q., Dong, B.D., Qiao, Y.Z., Liu, M.Y., and Zhang, J.W. 2010. Root growth, soil water available, and water-use efficiency of winter wheat under different irrigation regimes applied at different growth stages in North China. Agricultural Water Management 97:1676-1682.

López-Bellido, R.J., López-Bellido, L., Benítez-Vega, J., and López-Bellido, F.J. 2007. Tillage system, preceding crop, and nitrogen fertilizer in wheat crop: II. Water utilization. Agronomy Journal 99:66-72.

McDermott, B., and Coe, R. 2012. An easy introduction to biplots for multi-environment trials. 62 p. University of Reading, Reading, UK, and World Agroforestry Centre, Nairobi, Kenya.

Moreno-Ramos, O.H., Rodríguez-Casas, J., Canseco-Vichis, E.P., Martin, E., Herrera-Andrade, H., y Turrent, A. 2010. Época de aplicación del primer riego y densidad de plantas en el cultivo de trigo. Biotecnia 12(3):32-41.

Passioura, J.B., and Angus, J.F. 2010. Improving productivity of crops in water-limited environments. Advances in Agronomy 106:37-75.

Solís, E., Huerta, J., Pérez, P., Ramírez, A., Villaseñor, HE, Espitia, E., et al. 2008. Urbina S2007: nueva variedad de trigo harinero para la región 'El Bajío'. Agricultura Técnica en México 34(1):113-118.

Solís, E., Huerta, J., Pérez, P., Villaseñor, H.E., Ramírez, A., y de la Cruz, M.L. 2016. Alondra F2014, nueva variedad de trigo harinero para el Bajío, México. Revista Mexicana de Ciencias Agrícolas 7(5):1225-1229.

Solís, E., Huerta, J., Villaseñor, H.E., Pérez, P., Ramírez, A., Ledesma, L., et al. 2014. Luminaria F2012, nueva variedad de trigo harinero para riego restringido en El Bajío. Revista Mexicana de Ciencias Agrícolas 5(2):325-330.

Solís, E., Villaseñor, H.E., Ramírez, A., Rodríguez, M.F., Espinosa, E., y Hortelano, R. 2009. Respuesta de variedades de trigo al riego restringido en El Bajío. Folleto Técnico No 2. 6 p. Instituto Nacional de Investigaciones Forestales, Agrícolas y Pecuarias (INIFAP), Campo Experimental Bajío, Celaya, Guanajuato, México.

Steduto, P., Hsiao, T.C., Fereres, E., and Raes, D. 2012. Crop yield response to water. FAO Irrigation and Drainage Paper Nr 66. 510 p. Food and Agriculture Organization of the United Nations (FAO), Rome, Italy.

Tardieu, F. 2013. Plant response to environmental conditions: assessing potential production, water demand, and negative effects of water deficit. Frontiers in Plant Physiology 4:17. doi:10.3389/fphys.2013.00017.

Villaseñor, H.E., Huerta, J., Solís, E., Espitia, E., Ireta, J., y Galván, R. 2012. Norteña F2007, nueva variedad de trigo para siembras de riego en la región norte y El Bajío de México. Revista Mexicana de Ciencias Agrícolas 3(1):207-2012. 